Nippon Suisan Gakkaishi $\quad$ 75(1), 45-53 (2009)

\title{
三宅島の火山灰を利用したテングサ海藻礁の 開発とその効果の検証
}

\author{
滝尾健二, $1 *$ 安藤和人, ${ }^{1 \mathrm{a}}$ 杉野隆, $1 \mathrm{~b}$
}

駒 澤一朗, 1a 中村千 穂, $2 \mathrm{c}$ 荒川久幸 ${ }^{2}$

(2007 年 12 月 4 日受付, 2008 年 9 月 17 日受理)

1東京都島しょ農林水産総合センター大島事業所，2東京海洋大学海洋環境学科

Development and testing of blocks made from Miyakejima Island volcanic ash for the restoration of Gelidium beds

\section{KENJI TAKIO, ${ }^{*}$ KAZUTO ANDO, ${ }^{1 a}$ TAKASHI SUGINO, ${ }^{1 b}$ ICHIRO KOMAZAWA, ${ }^{\text {a }}$ CHIHO NAKAMURA ${ }^{2 c}$ AND HISAYUKI ARAKAWA ${ }^{2}$}

\begin{abstract}
${ }^{1}$ Oshima Branch, Tokyo Metropolitan Islands Area Research and Development Center of Agriculture, Forestry and Fisheries, Oshima, Tokyo 100-0212, ${ }^{2}$ Department of Ocean Sciences, Tokyo University of Marine Science and Technology, Minato, Tokyo 108-8477, Japan
\end{abstract}

Using volcanic ash and/or scoria collected from Miyakejima Island, 6 blocks (L30 $\times \mathrm{W} 30 \times \mathrm{H} 5 \mathrm{~cm})$ of different compressive strengths and composition were formed and deployed in Sashikiji fishing harbor, Izu Oshima Island to compare the coverage of colonized marine algae with concrete blocks of the same type. The coverage of red algae on the upper surface of volcanic ash blocks was significantly lower than that on a concrete block. No significant differences were found among the coverages on the 6 volcanic ash blocks of different compressive strength and composition. Gelidiacean algae did not grow on the upper surface but on the edge and lateral surfaces of these blocks. In the second experiment, columnar blocks $(\phi 5 \times \mathrm{H} 10 \mathrm{~cm})$ were deployed in the same fishing harbor. Gelidiacean algae grew on the lateral surface of these blocks and the amount of these algae was only slightly smaller than that on concrete blocks of the same shape.

キーワード : 海藻礁, 火山灰, テングサ, 三宅島

三宅島および周辺海域では, 2000 年 6 月に始まった 雄山の大規模な噴火により多量の火山灰が堆積し, ま た，島に堆積した火山灰の一部が降雨のたびに泥流とな って海へ流出した。三宅島の東側の磯根漁場はテングサ の好漁場を形成している場所が多い1)が，泥流被害は特 にこの地域で大きく, 漁場の埋没によりテングサが枯死 するなど，多くの磯根漁場が荒廃した。 ${ }^{2)} 2000$ 年の噴火 時の島全体への火山灰の堆積量は約 3,300 万 $\mathrm{t}$ （東京大 学地震研究所ホームページ: http://www.eri.u-tokyo. ac.jp/nakada/1022dep.html） と膨大であったため，火
山灰流出対策として，砂防ダムの整備が進められている （東京都三宅支庁ホームページ：http:// www.soumu. metro.tokyo.jp / 14miyake / miyakehp / )。しかしなが ら, 現在でも周辺海域への泥流の流出は続いており, テ ングサ漁場の多くは噴火以前の状態にまで回復していな い。3) また，三宅島はマクサ Gelidium elegans，やオオ ブサ G. pacificum を採取するテングサ漁業への依存度が 大きく, 漁獲量は噴火前年の 1999 年には約 $260 \mathrm{t}$ （漁 獲金額で全体の約 $22 \%)^{4)}$ を占めていたが，漁業が再開 された 2005 年は, 約 $17 \mathrm{t}$ (漁獲金額で全体の約 $13 \%)^{5)}$

* Tel : 81-04992-4-0381. Fax : 81-04992-4-0383. Email : takio@ifarc.metro.tokyo.jp

a 現所属 : 東京都島しょ農林水産総合センター八丈事業所 (Hachijo Branch, Tokyo Metropolitan Islands Area Research and Development Center of Agriculture, Forestry and Fisheries, Mitsune, Hachijo, 100-1511, Japan)

b 現所属：東京都建設局公園緑地部 (Bureau of Construction Tokyo Metropolitan Government, Shinjyuku, Tokyo 163-8011, Japan)

c 現所属：アクアマリンふくしま (Aquamarine Fukushima, Iwaki, Fukushima, 971-8101, Japan) 
と激減している。これらのことから，陸上の火山灰の処 理, 周辺海域への流出防止抒よび荒廃したテングサ漁場 の再生が急務となっている。

本研究では, 島に堆積した火山灰の処理と荒廃したテ ングサ漁場の再生を目的として, 三宅島の火山灰を利用 した海藻礁の開発を試み, テングサの着生効果を検証し たので報告する。

\section{材料および方法}

火山灰およびスコリアの採集とその性質 2001 年 11 月打よび 2002 年 1 月に三宅島へ上陸して火山灰の採集 を行った。火山灰の採集は村営牧場に隣接する青少年研 修センター（図中記号 a ; 以下「村営牧場」と記す。） と西部の阿古（記号 b）の2 箇所（Fig. 1) で行った。 村営牧場では青少年研修センターの軒下と地面上に降灰 していた火山灰, 阿古では噴火直後に土囊に詰められて いた火山灰を採集したが，これらはいずれも野外で風雨 に曝されていた。このほか, 島南部の角屋敷（記号 c)

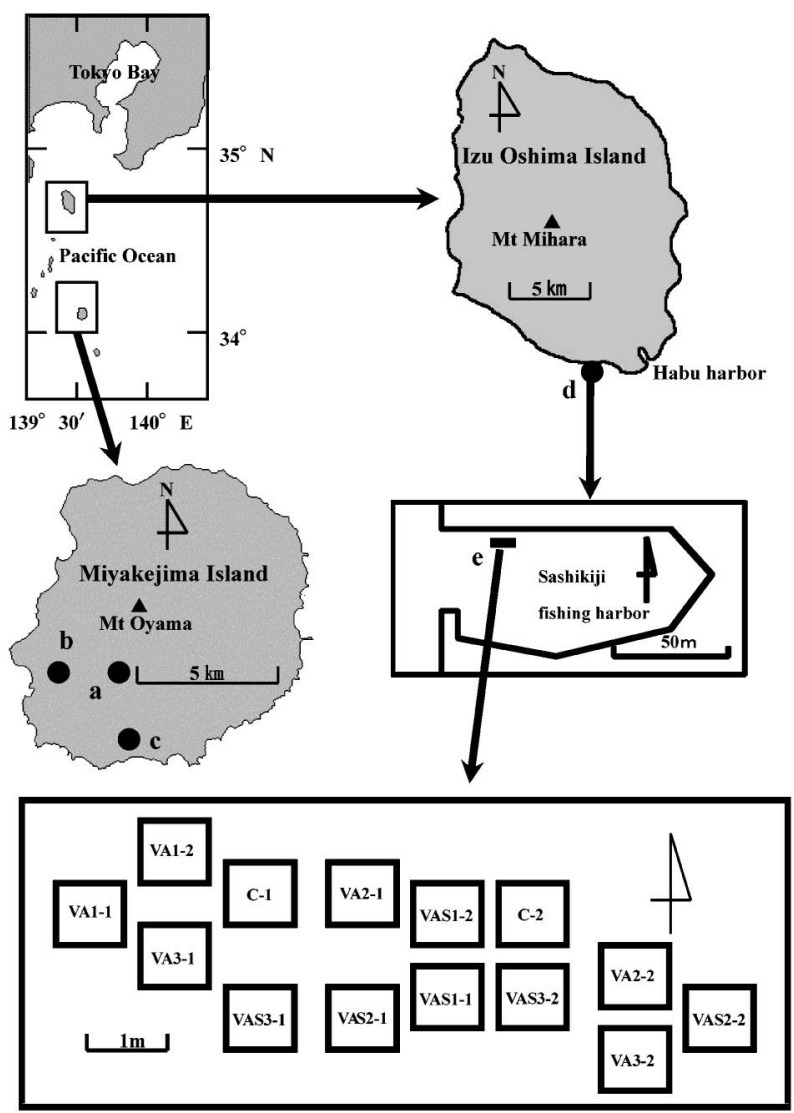

Fig. 1 Map showing the locations where volcanic ash was collected $(a-c)$, and location where the experimental blocks were deployed (d) and arranged (e). a: Village farm, b: Ako, c: Kadoyashiki, d: Sashikiji fishing harbor, e: Location where the experimental blocks were arranged.
においては, 1983 年の噴火の際に堆積し風雨に暴され ていたと推察されるスコリア（砂利様の溶岩石）を採集 した。

これらの火山灰抢よびスコリアについて, 粒径分布, 比重抢よび鉱物組成の測定を行った。火山灰の粒径は コールターLS200（ベックマンコールター社製）によ り粒径 $0.375 \sim 2000 \mu \mathrm{m}$ の範囲で計測した。粒径分布は 約 $1 \sim 2000 \mu \mathrm{m}$ で, 村営牧場では $30 \mu \mathrm{m}$, 阿古では 30 〜250 $\mu \mathrm{m}$ の数力所にモードが認められた。スコリアに ついては, 試料の中から無作為に500 個を選出し, ノ ギス（精度 $0.05 \mathrm{~mm}$ ）で直径を計測したところ, 粒径 範囲は 8.65 $58.75 \mathrm{~mm}$ で, モードは $23.2 \mathrm{~mm}$ であっ た。比重 (JSF-T1116)に準じて測定) は, 火山灰では 2.77〜2.82 の範囲，スコリアでは 2.64 であった。また，

X 線回折装置 RINT2000（Rigaku Co.）を使用して火 山灰の鉱物組成を調べたところ, スメクタイト類, 緑泥 石類, イライト, カオリナイト, 石英, 打よび長石が検 出され, 特にスメクタイト類と長石の含有量が多かっ た。

実験に用いた試験礁の組成, 形状および圧縮強度 本 研究では, まず, 阿古の火山灰や角屋敷のスコリアをセ メントと混合して, 材料組成や圧縮強度の異なる 6 種 類の試験礁（以下, 火山灰ブロック, 火山灰スコリアブ ロック）を製作して海底に沈め, コンクリート製の試験 礁（以下，コンクリートブロック）との間でテングサお よびその他の紅藻類の繁茂状況を比較した。なお，これ ら 7 種類の試験礁 $(\mathrm{L} 30 \times \mathrm{W} 30 \times \mathrm{H} 5 \mathrm{~cm})$ は 2 供試体ず つ製作した。Table 1 に各試験礁の材料組成と圧縮強度 を示した。火山灰ブロックは圧縮強度の低いほうから VA1, VA2, VA3 とし, 火山灰スコリアブロックは压縮 強度の低いほうからVAS1, VAS2, VAS3 とした。Cは 対照としたコンクリートブロックである。試験礁は各 2 供試体あるため, 例えばVA1-1, VA1-2 の様に, それ ぞれ番号をつけ識別した。各試験礁の圧縮強度は, アム スラー式圧縮試験機（前川試験機製作所製）を用いて測 定した。火山灰ブロックの圧縮強度は, VA1（セメン 卜含有率 $20 \%$ ) で $6.1 \mathrm{kgf} / \mathrm{cm}^{2}, \mathrm{VA} 2(35.7 \%)$ で 38.7 $\mathrm{kgf} / \mathrm{cm}^{2}$, VA3 (50\%) で $201.9 \mathrm{kgf} / \mathrm{cm}^{2}$ ，火山灰スコリ アブロックは, VAS1（セメント含有率 10.1\%）で 31.6 $\mathrm{kgf} / \mathrm{cm}^{2}, \mathrm{VAS} 2(20 \%)$ で $96.9 \mathrm{kgf} / \mathrm{cm}^{2}, \mathrm{VAS} 3(35.2$ $\%$ ) で $221.3 \mathrm{kgf} / \mathrm{cm}^{2}$, コンクリートブロック (c) は $147.9 \mathrm{kgf} / \mathrm{cm}^{2}$ であった。また, 試験終了時における圧 縮強度については, 台座からの取り外しが困難と判断 し, 測定を行わなかった。なお, 各試験礁の表面の粗さ は, ブロックの製作時にブロックの表面に粗骨材が露出 しないよう配慮したため, ほぼ同一と考えられた。

上記の 7 種類の試験礁を用いた組成・圧縮強度別試 験の終了後, 新たに円柱形 $(\phi 5 \times \mathrm{H} 10 \mathrm{~cm})$ の試験礁を 
Table 1 Composition and compressive strength of the experimental blocks

\begin{tabular}{|c|c|c|c|c|c|c|c|}
\hline \multicolumn{3}{|c|}{ Experimental blocks } & \multicolumn{4}{|c|}{ Material composition } & \multirow{2}{*}{$\begin{array}{l}\text { Compressive } \\
\text { strength } \\
\left(\mathrm{kgf} / \mathrm{cm}^{2}\right)\end{array}$} \\
\hline & $\begin{array}{l}\text { Block } \\
\text { No. }\end{array}$ & $\begin{array}{l}\text { Nnmber } \\
\text { of blocks }\end{array}$ & $\begin{array}{l}\text { Volcanic } \\
\text { ash (kg) }\end{array}$ & $\begin{array}{c}\text { Scoria } \\
(\mathrm{kg})\end{array}$ & $\underset{(\mathrm{kg})}{\text { Cement }}$ & $\begin{array}{l}\text { Water } \\
(\mathrm{kg})\end{array}$ & \\
\hline \multirow{3}{*}{$\begin{array}{l}\text { Volcanic ash, } \\
\text { Cement, Water }\end{array}$} & VA1 & 2 & 5.6 & & 1.4 & 3.5 & 6.1 \\
\hline & VA2 & 2 & 4.5 & & 2.5 & 3.5 & 38.7 \\
\hline & VA3 & 2 & 3.5 & & 3.5 & 3.5 & 201.9 \\
\hline \multirow{3}{*}{$\begin{array}{l}\text { Volcanic ash, } \\
\text { Cement, Scoria, } \\
\text { Water }\end{array}$} & VAS1 & 2 & 3.1 & 3.1 & 0.7 & 2.3 & 31.6 \\
\hline & VAS2 & 2 & 2.8 & 2.8 & 1.4 & 2.3 & 96.9 \\
\hline & VAS3 & 2 & 2.3 & 2.3 & 2.5 & 2.3 & 221.3 \\
\hline Concrete & $\mathrm{C}$ & 2 & \multicolumn{4}{|c|}{ (General concrete $10 \mathrm{~kg}$ ) } & 147.9 \\
\hline
\end{tabular}

製作した。円柱形の試験礁は原料として火山灰を使用し たブロック（以下円柱形火山灰ブロック）およびコンク リートブロック（以下円柱形コンクリートブロック）を 各 8 本とした。円柱形火山灰ブロックは村営牧場の火 山灰を使用して製作し，その配合はVA3 の場合と同様 とした。また，これらブロック表面の粗さは組成・圧縮 強度別試験礁同様に製作したため, ほぼ同一と考えられ た。

試験礁の追跡調査 組成・圧縮強度別試験礁はコンク リート製の台座 $(\mathrm{L} 60 \times \mathrm{W} 60 \times \mathrm{H} 15 \mathrm{~cm})$ の上面に固定 し, 2002 年 5 月 31 日に伊豆大島差木地漁港 (Fig. 1, 記号 d）の水深約 $3 \mathrm{~m}$ の海底に設置（記号 e）した。ま た，円柱形の試験礁は別のコンクリート製台座（L80× $\mathrm{W} 80 \times \mathrm{H} 20 \mathrm{~cm})$ の上面に 4 本ずつ取り付け，2005 年 8 月 5 日に先の試験礁に隣接して設置した。なお, 差木 地漁港の海底は転石交じりの砂の底質であったため, 試 験礁は大きな転石を避けて，できるだけ水平になるよう 設置した。試験礁の設置時期については, 静岡県稲取町 地先のマクサとオオブサおよび千葉県小湊町地先のマク サの生殖形成及び成熟の時期を 5 月中旬 10 月下旬と 報告した殖田7)を参考に，この期間内の設置に努めた が, 円柱形の試験礁に関しては, 製作と設置準備の遅れ のために組成・圧縮強度別試験の開始時期と約 2 ヶ月 のずれが生じた。

組成・圧縮強度別試験礁の追跡調査は設置から 20 日, 74 日， 102 日， 140 日，203 日，251日，320日，404 日，468 日，560日抢よび 648 日目にスクーバ潜水し， 目視観察および写真撮影により行った。目視観察では, テングサの着生状況, その他の海藻の着生状況, 試験礁 の表面形状の変化打よび植食動物の出現状況を確認し た。また, 写真撮影では, 試験礁上面に抢ける紅藻類 （石灰藻を除く, 紅色を示す海藻）の入植, 推移の比較 を試み, 組成・圧縮強度別試験終了後に製作した円柱形 の火山灰ブロックの材料組成を決める際の参考とした。

写真はステンレス製架台により海藻礁最上面からの距
離 $45 \mathrm{~cm}$ に固定されたデジタルカメラ（SONY 製, Model : DSC-P1, 総画素数 : 3.3 mega pixel) で撮影 した。撮影された画像は画像処理ソフト (Adobe 社製 Photoshop）に取り込み, 設置から 203 日目の 2002 年 12 月 19 日以降の画像について「色域指定」コマンドを 使って調査日毎に特定の色域を選択し, 紅藻類の被度を 求めた。また, 各試験礁の紅藻類被度について, Tukey の多重比較による検定を行い, 試験礁の組成・圧縮強度 と紅藻類被度の関係について検討した。被度の検定は, 各試験礁の画像を同様に 9 分割した後, 各区画の被度 を求め, 2 供試体上に試験区が 18 ずつ存在すると仮定 して調査日毎に行った。

なお, 円柱形の試験礁については, 設置から707日 目に海底の台座から取り外して持ち鹵り, 着生していた テングサの直立体数と各々の藻体長を測定した。

試験礁設置場所の環境調査 試験礁周辺の海藻相と生 育量を調べるため, 差木地漁港内をスクーバ潜水し, 2002 年 6 月 27 日には港内ほぼ全域に抢ける目視観察, 2002 年 12 月 19 日, 2003 年 4 月 15 日, および 2003 年 7 月 11 日には枠取り調査を行った。枠取り調查では 各回とも任意に選択した $1 \mathrm{~m}^{2}(1 \mathrm{~m} \times 1 \mathrm{~m}$ 方形枠 $)$ 内の 海藻を試験礁の周囲の岩礁上から採集し, 実験室に持ち 帰り, 脱水機で 5 分間脱水の後, 種の同定と湿重量の 測定を行った。差木地漁港の海底は転石交じりの砂の底 質であった。試験礁周辺の水温打よび塩分は, メモリー 式の水温塩分計（アレック電子社製 $\mathrm{ACT}-\mathrm{HR}$ ）を差木 地漁港内の海底に固定して測定した。ただし，2002 年 5 月 31 日 $~ 11$ 月 26 日, 2003 年 4 月 18 日 6 月 2 日 抢よび 2003 年 8 月 22 日〜 12 月 10 日の間は測器が未 設置あるいは故障のため欠測となっている。この期間の 水温を補完するために, 差木地漁港から約 $2 \mathrm{~km} の$ 東方 にある波浮港口における海面水温データ（デジタル温度 計；村山電気 Handy Thermo D-54）を参照した。 


\section{結果}

組成・圧縮強度別試験礁の目視観察による追跡調査 海中設置後における試験礁の目視観察状況は次の通りで あった。

設置 20 日目 $(2002$ 年 6 月）には， 7 種類すべての礁 において珪藻類がほぼ全面を覆っていた。

74 日目（2002 年 8 月）には， 7 種類すべての礁にお いて無節サンゴモ類がほぼ全面に観察され，無節サンゴ モの上にアオサ類と珪藻類が繁茂していた。また，14 礁中 4 礁（VA1-2, VA2-2, VAS1-1, VAS2-1）は裏返 しになっていたため元の状態に戻したが，これらの礁に おける海藻着生量は他のものに比べて少なかった。な お，裏返しになっていなかった試験礁抢よび台座の上面 のほぼ全面に約 $5 \mathrm{~mm}$ 以下の厚さで砂の堆積が見られた。

102 日目（2002 年 9 月）には， 7 種類すべての礁に おいてアオサ類の着生量が減少していた。一方，微細な 系状紅藻類が繁茂していた。なお，この日以降，各調査 日に抢いて，全ての試験礁抢よび台座の上面のほぼ全面 に約 $5 \mathrm{~mm}$ 以下の厚さで砂の堆積が見られた。

140 日目（2002 年 10 月）には，10月 1 日に接近し た台風 21 号による時化の影響で，礁全体あるいは礁の 一部分が砂中に埋没したため, 掘り出し作業を行った。 全体が埋没していた試験礁は，VA1-2，VA3-2，VAS21, C-1の 4 礁，一部が埋没した試験礁は，VA2-2, VAS1-2 の 2 礁であった。埋没部分の海藻は白化し， 着生海藻が著しく減少していたが，非埋没部分の海藻着 生状況は前回調査時と比べて顕著な変化は認められなか った。

203 日目（2002 年 12 月）には，すべての礁に抢いて 紅藻類, 特にトゲイギス Centroceras clavulatum とフシ ツナギLomentaria catenata の着生が目立った。その他 にはアオサ類等が見られた。なお，この日以降，全調査 日に扔いて，試験礁には紅藻類が，緑藻類抢よび褐藻類 に対して明らかに優占して着生していた。

251 日目（2003 年 2 月）には，14 礁中 3 礁（VAS22, VAS3-2, C-2) でマクサの着生を確認できた。また， マクサの株数は各礁とも 1 株で, 着生箇所は稜角 (Fig. 2a），抒よび傾の部分であった。な㧍，着生量が多い 海藻はトゲイギスとフシッナギであり，その他にはアオ サ類, サイダイバラ Hypnea saidana，トサカマッ Prionitis crispata，有節石灰藻類等が見られた。

320 日目（2003 年 4 月）には, 試験礁に着生したマ クサは明らかに生長していたが，株数には変化がなかっ た。また，フシッナギが大きく生長していた。その他に はアオサ類，トゲイギス，スギノリ Gigartina tenella,

トサカマツ，有節石灰藻類等が見られた。

404 日目（2003 年 7 月）には, 試験礁に着生したマ
クサは明らかに生長していたが，株数には変化がなかっ た。また，前回の調査で大きく生長していたフシツナギ の着生量が著しく減少していた。その他には，アオサ 類, トサカノリMeristotheca papulosa，スギノリ，ツノ ムカデ Prionitis cornea, トサカマッ, 有節石灰藻類等 が見られた。

468 日目（2003 年 9 月）には, 試験礁に着生してい るマクサはほとんど生長していない様子で，株数にも変 化がなかった。また，マクサの表面は珪藻類や糸状緑藻 類に覆われていた。その他には, スギノリ, ッノムカ デ，トサカマツ，有節石灰藻類等が見られた。

560 日目（2003 年 12 月）には, 前回調査時にマクサ の表面に着生していた珪藻類や系状緑藻類は減少してお り，新たに 2 試験礁（VA1-1, VA2-1）でマクサの着生 が確認され，マクサの着生する試験礁が 5 礁となった。 VA1-1, VA2-1に打けるマクサの株数は各礁 1 株で, 着生箇所はいずれも稜角であった。また，すでに着生し ているマクサはほとんぞ生長していない様子であり, VAS3-2, C-2 では，株数にも変化がなかった。一方， VAS2-2 では，新たにマクサの着生が確認され，この礁 に打けるマクサの株数が 2 株となった。なお，全ての 礁に抢いて，トゲイギスと有節石灰藻類の着生が目立っ た。

648 日目（2004 年 3 月）には, 試験礁に着生したマ クサは明らかに生長していたが，株数に変化は無かっ た。その他にはフシツナギ，トゲイギス，トサカノリ， スギノリ，有節石灰藻類等が見られた。また，この時点 において，テングサの着生している試験礁は組成および 圧縮強度が異なる 5 礁であり，株数も 4 礁が 1 株， 1 礁 が 2 株と少ないため, 組成打よび圧縮強度によるテン グサの着生状況の比較が困難と判断し，追跡調査を終了 した。

な抢，今回，台座等，試験礁以外の部分については， テングサの着生量の調査は行わなかったが，設置後，台 座の稜角や側面，試験礁移設用の金具，識別用のタグな ぞ，水平面でないところや不安定に動摇する場所にマク サの着生が見られた（Fig. 2b)。また，各試験礁の表面 形状については明らかな変化は認められなかった。植食 動物については試験礁上および試験礁周辺においてメジ ナ類やクボガイ類が観察されたが，個体数に関して，特 定の試験礁への偏りは認められなかった。なお，これら の生物による海藻の被食状況については調査を行わなか ったため不明である。

紅藻類の被度の推移 今回, 組成・圧縮強度によるテ ングサの着生量の比較は困難であった。一方，目視観察 によれば, 203 日目（2002 年 12 月）以降, 全ての試験 礁に扔いて, 紅藻類が緑藻類抢よび褐藻類に対して優占 して着生しており，また，各試験礁に着生した紅藻類の 

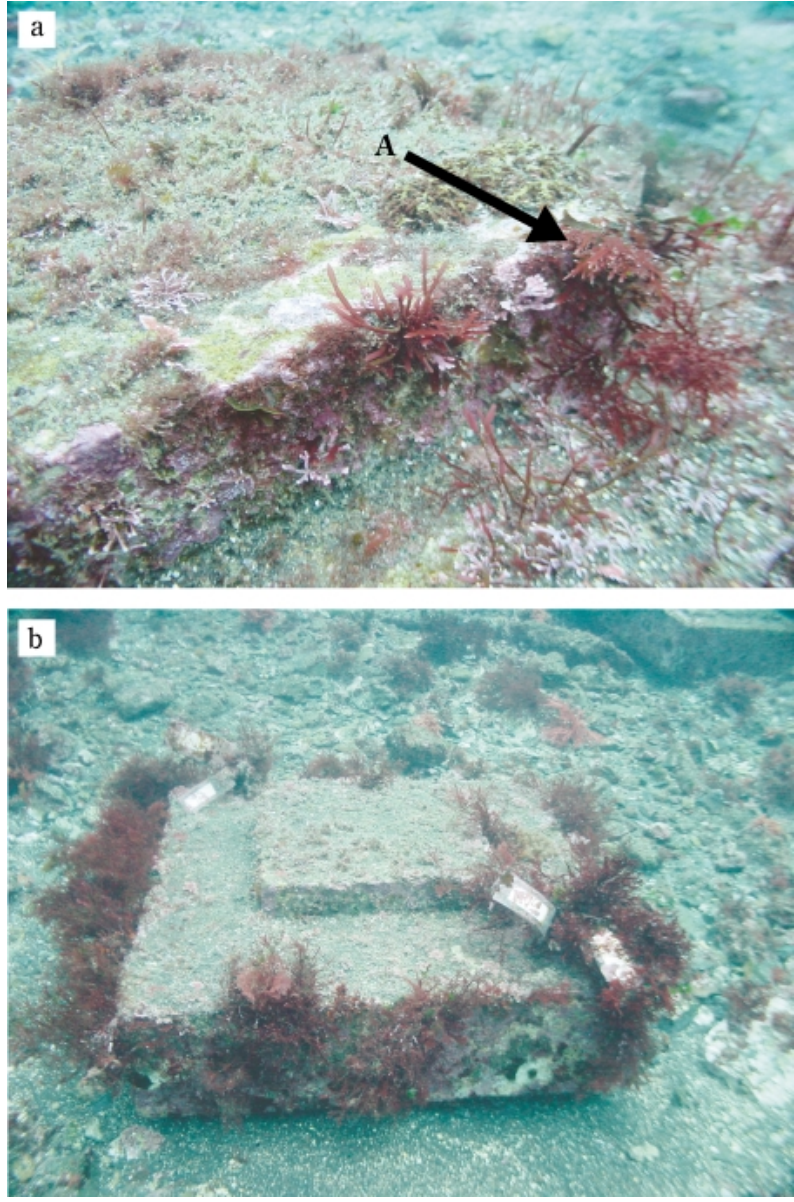

Fig. 2 Experimental blocks on the 251st day (a), and the 648th day (b) after being installed on a concrete mound. A: Gelidium elegans growing on an edge of the block (VAS3-2).

種には顕著な違いは認められなかった。そこで, 試験礁 上面の画像から求めた紅藻類の被度の比較を行い, 本試 験終了後に行った円柱形の火山灰ブロックの材料組成を 決める際の参考とした。

紅藻類の被度の変化についてみてみる。試験礁上面の 画像に含まれる紅藻類は, 目視観察から, マクサ, トゲ イギス，フシッナギ，スギノリ，トサカノリ，トサカマ ツ, ツノムカデ, サイダイバラ等であったと考えられた。 2002 年 12 月 19 日（203 日目）以降における試験礁上 面の紅藻類の被度を Table 2 に示した。

紅藻類の被度は，203 日目（2002 年 12 月）は $7.0 〜$ $12.5 \%$ の範囲, 251 日目（2003 年 2 月）は $20.5 \sim 28.1$ $\%$ 範囲で, この間, 被度が上昇傾向にあった。一 方, 両日とも試験礁間で有意差は無かった。320日目 (2003 年 4 月) は $11.9 \sim 29.3 \%$ の範囲であり, VA3, VAS2, VAS3 では被度が増大, VA2, Cでは横ばい, VA1, VAS1では低下した。また，VA1，VAS1の被度 は, VAS2, VAS3, Cの 3 礁に対して有意に低かった
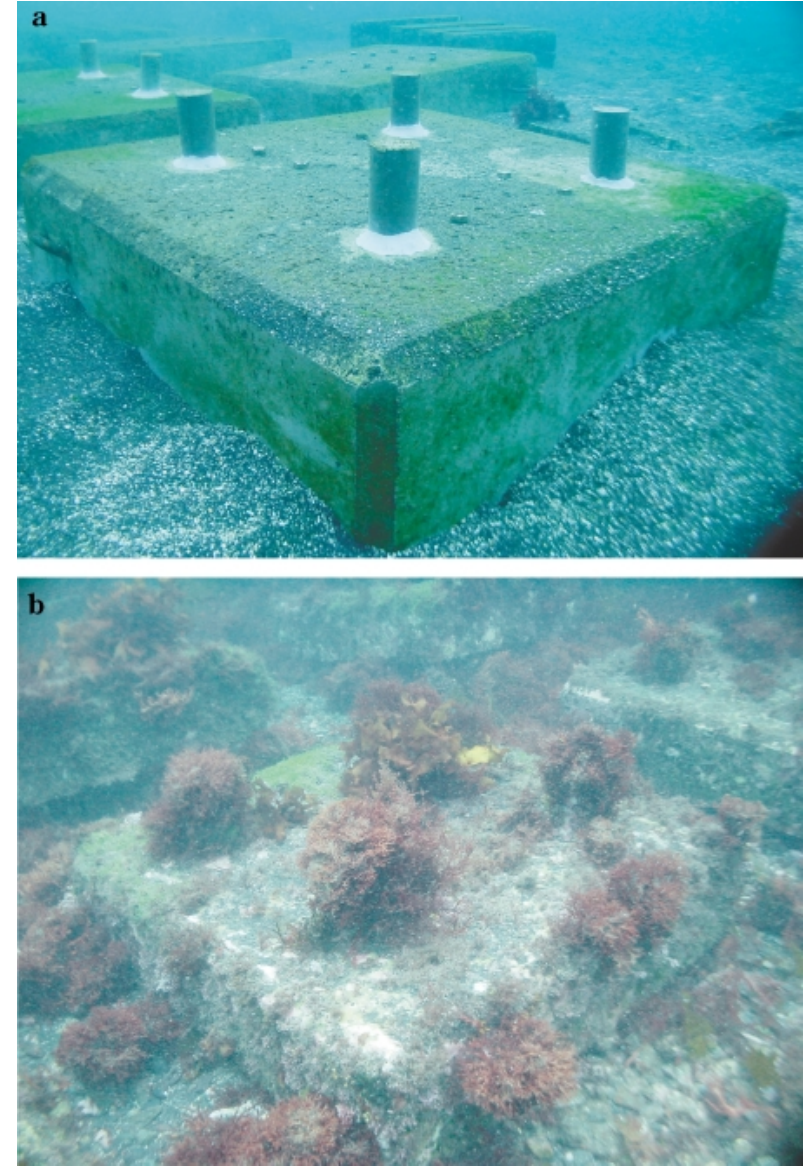

Fig. 4 Columnar volcanic ash blocks on the 7th day (a) and the 707th day (b) after being installed on a concrete mound.

$(P<0.05)$ 。 404 日目（2003 年 7 月） 加ら 468 日目 (2003 年 9 月) の間では, 被度が $1.6 \sim 15.2 \%$ の範囲で あり,すべての礁において，320日目と比較して低下傾 向であった。また，468 日目では，コンクリートブロッ ク C の被度が VAS3 以外の 5 種類の礁に対して有意に 高かった $(P<0.05)$ 。560日目（2003 年 12 月）では紅 藻類の被度は $11.8 \sim 24.2 \%$ の範囲となり，すべての礁 で増大して打り，コンクリートブロックCの被度が VA1, VAS2 の 2 礁に対して有意に高かった $(P<0.05)$ 。 648 日目（2004 年 3 月）では紅藻類の被度は 14.1 $50.2 \%$ となり, VA2 およびVAS1 では横ばいであった が，他の礁では増大した。また，コンクリートブロック $\mathrm{C}$ の被度はVAS2 以外の 5 種類の礁に対して有意に高 かった $(P<0.05)$ 。

以上, 組成 ・圧縮強度別試験礁における海藻着生状況 に関する定量的な調査は試験礁上面の紅藻類被度の画像 解析だけしか行わなかったが, 目視観察によれば, 試験 礁側面抢よび台座の側面に抢ける（マクサを含む）紅藻 類の被度は試験礁上面と比較して明らかに高かった 
Table 2 Temporal change in the red algae coverage of each experimental block

$($ mean \pm S.D., $n=18)$

\begin{tabular}{|c|c|c|c|c|c|c|c|c|c|}
\hline \multirow{2}{*}{$\begin{array}{c}\text { Material } \\
\text { composition of } \\
\text { experimental block }\end{array}$} & \multirow{2}{*}{$\begin{array}{c}\text { Block } \\
\text { No. }\end{array}$} & \multirow{2}{*}{$\begin{array}{c}\text { Compressive } \\
\text { strength } \\
\left(\mathrm{kgf} / \mathrm{cm}^{2}\right)\end{array}$} & \multicolumn{7}{|c|}{ Coverage of red algae $(\%)$} \\
\hline & & & 2002.12 .19 & 2003.2 .5 & 2003.4 .15 & 2003.7 .8 & 2003.9 .10 & 2003 & 2004.3 .8 \\
\hline \multirow{3}{*}{$\begin{array}{l}\text { Volcanic ash, } \\
\text { Cement, Water }\end{array}$} & VA1 & 6.1 & 10.5 & $24.0 \pm$ & $11.9 \pm 11.0^{\circ}$ & $4.4 \pm$ & $4.4 \pm$ & $11.0 \pm 1 . \gamma^{2}$ & \\
\hline & VA2 & 38.7 & $7.0 \pm 5.4^{\mathrm{a}}$ & $20.9 \pm 9.6^{\mathrm{a}}$ & $20.4 \pm 16.6^{\mathrm{a}, \mathrm{b}}$ & $9.2 \pm 13.5^{\mathrm{a}}$ & $2.0 \pm 2.5^{\mathrm{a}}$ & $15.4 \pm 10.8^{\mathrm{a}, \mathrm{b}}$ & $14.1 \pm 10.4^{\mathrm{a}}$ \\
\hline & VA3 & 201.9 & $8.3 \pm 6.2^{\mathrm{a}}$ & $20.5 \pm 6.8^{\mathrm{a}}$ & $23.8 \pm 21.0^{\mathrm{a}, \mathrm{b}}$ & $9.0 \pm 5.2^{\mathrm{a}}$ & $1.6 \pm 3.3^{\mathrm{a}}$ & $19.8 \pm 6.4^{\mathrm{a}, \mathrm{b}}$ & 24.3 \\
\hline \multirow{3}{*}{$\begin{array}{l}\text { Volcanic ash, } \\
\text { Cement, Scoria, } \\
\text { Water }\end{array}$} & VASI & & $9.5 \pm 7.8^{a}$ & $27.3=$ & $13.9 \pm 7.9^{\mathrm{a}}$ & $8.3=$ & $5.7 \pm$ & $18.6 \pm 8.3^{\mathrm{a}, \mathrm{b}}$ & $17.3 \pm$ \\
\hline & VAS2 & 96.9 & $12.1 \pm 9.6^{\mathrm{a}}$ & $20.5 \pm 7.9^{\mathrm{a}}$ & $29.3 \pm 10.7^{b}$ & $8.1 \pm 5.4^{\mathrm{a}}$ & $3.7 \pm 3.5^{\mathrm{a}}$ & $13.0 \pm 10.0^{\mathrm{a}}$ & $32.8 \pm 21.4^{\mathrm{a}, \mathrm{b}}$ \\
\hline & VAS3 & 221.3 & $12.5 \pm 10.1^{\mathrm{a}}$ & $24.3 \pm 6.2^{\mathrm{a}}$ & $29.6 \pm 12.0^{\mathrm{b}}$ & $6.1 \pm 5.7^{\mathrm{a}}$ & $8.8 \pm 9.1^{\mathrm{a}, \mathrm{b}}$ & $18 \pm 13.8^{\mathrm{a}, \mathrm{b}}$ & $24.4 \pm 21.3^{\mathrm{a}}$ \\
\hline Concrete & C & 147.9 & $11.0 \pm 8.7^{\mathrm{a}}$ & $28.1 \pm 6.9^{\mathrm{a}}$ & $28.8 \pm 14.4^{\mathrm{b}}$ & $6.5 \pm 4.3^{\mathrm{a}}$ & $15.2 \pm 16.8^{b}$ & $24.2 \pm 11.2^{\mathrm{b}}$ & $50.2 \pm 29.4^{\mathrm{b}}$ \\
\hline
\end{tabular}

Vertical (a, b) values between different blocks not sharing the same superscript letters are significantly different $(P<0.05)$

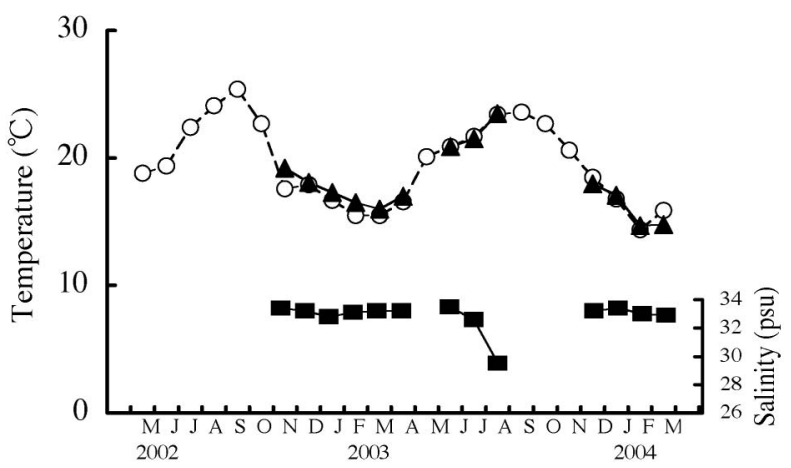

Fig. 3 Changes in the monthly averages of water temperature and salinity. $\bigcirc$ : water temperature at Habu harbor, $\boldsymbol{\Lambda}$ : water temperature at Sashikiji fishing harbor, - : salinity at Sashikiji fishing harbor.

(Fig. 2b)。

試験期間中の水温, 塩分および試験礁周囲の海藻相 2002 年 5 月から 2004 年 3 月にかけての差木地漁港の 月別平均水温と塩分打よび波浮港口の月別平均水温を Fig. 3 に示した。差木地漁港と波浮港口の水温変動はよ く合致して抢り, 差木地漁港の欠測期間中の水温は, 波 浮港口と大差ないと考えられたので, 差木地漁港の月別 平均水温の最低值は 2004 年 2 月の $14.7^{\circ} \mathrm{C}$, 最高值は 2002 年 9 月の約 $25.4^{\circ} \mathrm{C}$, 平均值は約 $19.8^{\circ} \mathrm{C}$ とみなし た。また, 差木地漁港の塩分は, 2002 年 11 月から 2003 年 6 月までの間は $32.6 \sim 33.3 \mathrm{psu}$ の範囲であっ た。ただし， 2003 年 8 月には急激な低下が見られ，平 均 $29.5 \mathrm{psu}$ を示した。

Table 3 に, 2002 年 6 月 27 日に目視観察された海藻 種抢よび試験期間中 3 度実施した $1 \mathrm{~m}^{2}$ 枠取り調査の結 果を示す。枠取り調査で採取された種にはとの湿重量 （g）を示した。目視観察により，差木地漁港内におい て 44 種の海藻が確認され, テングサ（マクサ, オオブ サ）は転石, 岩礁上, 漁港岸壁など, ほぼ漁港内全域で
観察された。また, マクサは主に転石や岩礁上に, オオ ブサは主に漁港岸壁に着生が認められた。なお， 3 回の 枠取り調査に打ける紅藻類の湿重量は総重量の 99.9 100\%であり，その内マクサは $67.0 \sim 94.5 \%$ を占め, 常に最大であった。

円柱形の試験礁へのテングサの着生 組成・圧縮強度 別試験礁において, 側面や稜角抢よびその他の突起物に マクサの着生が観察されたことから，火山灰抢よびコン クリートを用いて鉛直面の多い試験礁, すなわち円柱形 火山灰ブロックと円柱形コンクリートブロックを製作し てテングサの着生について調査した。円柱型火山灰ブロ ックの材料組成は, 組成・圧縮強度別試験に扔いて, 火 山灰やスコリアを用いた 6 種類の試験礁の紅藻類被度 に 2003 年 4 月以外は有意差が認められなかったことか ら, VA3 の場合と同様の 1 種類とした。その結果, 設 置 707 日目（2007年 7 月）には, いずれのタイプのブ ロックでも鉛直面にオオブサの着生が確認された（Fig. 4)。オオブサは円柱形火山灰ブロックでは 8 本中 3 本 のブロックに合計 8 株 (平均藻長 $9.5 \mathrm{~cm}$ ), 円柱形コン クリートブロックは 8 本中 3 本のブロックに合計 10 株 (平均藻長 $10.7 \mathrm{~cm}$ ) 着生し, 円柱形火山灰ブロックヘ のオオブサの着生量は円柱形コンクリートブロックより も僅かに少ない程度であった。

\section{考察}

試験礁設置場所の環境とテングサの生育への影響 組 成 - 圧縮強度別試験期間中の差木地漁港の月別平均水温 をみると, 最低值は 2004 年 2 月の $14.7^{\circ} \mathrm{C}$, 最高值は 2002 年 9 月の約 $25.4^{\circ} \mathrm{C}$, 平均值は約 $19.8^{\circ} \mathrm{C}$ であった。 片田8)によれば，マクサの発芽体を $12.1^{\circ} \mathrm{C}$ から $34.3^{\circ} \mathrm{C}$ の間の各段階で 4 日間培養試験を行った結果, $28^{\circ} \mathrm{C}$ 以 上はほとんど枯死し， $24 \sim 25^{\circ} \mathrm{C}$ が好適であったとされ ている。したがって, 今回の調査期間内の水温は, 試験 礁に抬けるマクサの着生に障害のない值を示していたと 
Table 3 Marine algae observed and collected in a quadrat $(1 \times 1 \mathrm{~m})$ in Sashikiji fishing harbor

\begin{tabular}{|c|c|c|c|c|}
\hline \multirow{2}{*}{ Class } & \multirow{2}{*}{$\begin{array}{l}\text { Species observed in Sashikiji } \\
\text { fishing harbor }(2002.6 .27)\end{array}$} & \multicolumn{3}{|c|}{ Wet weight of algae collected from quadrat $(\mathrm{g})$} \\
\hline & & 2002.10 .19 & 2003.4 .15 & 2003.7 .11 \\
\hline \multirow{3}{*}{ Chlorophyceae } & Ulba pertusa & & & \\
\hline & Caulerpa subserrata & & & \\
\hline & Codium adhaerens & & & \\
\hline \multirow{10}{*}{ Phaeophyceae } & Dictyota dichotoma & & & \\
\hline & Spatoglossum pacificum & & & \\
\hline & Dilophus okamurae & & & \\
\hline & Dictyopteris prolifera & & & \\
\hline & Zonaria diesingiana & & & \\
\hline & Leathesia difformis & & & \\
\hline & Colpomenia sinuosa & & & \\
\hline & Eckloniopsis radicosa & & & \\
\hline & Sargassum macrocarpum & & & \\
\hline & S. micracanthum & 0.7 & & \\
\hline \multirow{31}{*}{ Rhodophyceae } & Galaxaura fastigiata & & & \\
\hline & G. falcata & & & \\
\hline & Asparagopsis taxiformis & & & \\
\hline & Delisea fimbriata & & & \\
\hline & Gelidium elegans & 468.4 & 746 & 507.1 \\
\hline & G. pacificum & & & \\
\hline & Chondrococcus japonicus & & & \\
\hline & Lithothamnium pideum & & & \\
\hline & Amphiroa dilatata & & & \\
\hline & Marginisporum crassissimum & & & \\
\hline & Grateloupia elliptica & & 12.3 & \\
\hline & G. imbricata & & & \\
\hline & Prionitis crispata & & & 39 \\
\hline & P. cornea & 24.1 & 11 & 177.1 \\
\hline & P. divaricata & & & 11.8 \\
\hline & P. angusta & & & \\
\hline & Callophyllis adhaerens & 1.9 & & \\
\hline & Meristotheca papulosa & & & 22.2 \\
\hline & Plocamium telfairiae & 0.6 & & \\
\hline & Hypnea japonica & & & \\
\hline & H. saidana & & & \\
\hline & Chondracanthus tenellus & & & \\
\hline & Chondrus ocellatus & & & \\
\hline & Lomentaria catenata & & & \\
\hline & Champia parvula & & & \\
\hline & Griffithsia subcylindrica & & & \\
\hline & Ceramium paniculatum & & & \\
\hline & Centroceras clavulatum & & & \\
\hline & Acrosorium yendoi & & & \\
\hline & Scinaia okamurae & & 25.7 & \\
\hline & Ahnfelitiopsis yamadae & & 20.5 & \\
\hline \multicolumn{2}{|c|}{ Total weight of algae collected from quadrat $(\mathrm{g})$} & 495.7 & 815.5 & 757.2 \\
\hline
\end{tabular}

考えられた。また，月別平均塩分は，2003 年 8 月に急 激な低下（29.5 psu）が見られたのを除き，32.6〜33.3 $\mathrm{psu}$ の範囲であった。山崎 9 によよれば，マクサは，かな
り発芽の進んだ発芽体は低比重海水に弱く, 淡水が海水 の 5 分の 1 位混入する状態では枯死するようであると されており, 今回観測された塩分值は, 急激に低下した 
2003 年 8 月を含め, 試験礁へのマクサの着生に障害に ならなかったと考えられた。さらに，3回の海藻の枠取 り調査に抢いて, 各回とも最も多く出現したのがマクサ であった (Table 3)。これらのことから, 試験期間中, 差木地漁港内の環境はマクサの着生打よび生育に適して いたと考えられる。

一方, 今回, 試験礁へのマクサの着生は僅かであっ た。大須賀, 岩橋 ${ }^{10)}$ は, 静岡県白浜地先に投石した $1 \mathrm{~m}$ 平方のコンクリートブロックの垂直面や平面にはテング サ（マクサ，オバクサ Pterocladia capillacea）の着生は 非常に少ないが，同じブロックでも海底で傾いたものの 斜面に拀いて非常に着生が良かったとしている。組成・ 圧縮強度別試験礁 $(\mathrm{L} 30 \times \mathrm{W} 30 \times \mathrm{H} 5 \mathrm{~cm})$ は水平面と垂 直面から成り, 海底に対してなるべく水平になるように 設置した。これらの事から，マクサの着生が僅かであっ た一因として, 試験礁の形状がマクサの着生に適してい なかった事が考えられた。また, 試験礁におけるマクサ の着生箇所は稜角や側面であり, 試験礁および台座の側 面における（マクサを含む）紅藻類の被度も, 試験礁上 面と比較して明らかに高かった。テングサの繁殖に影響 を与える環境条件としては, 潮流の動き, 水温, 海水の 動き, その他塩分, 栄養塩, 光などが考えられる ${ }^{9}$ が, 試験礁の稜角や側面は, 上面と比較して海水の動きや光 条件がマクサの着生に適していた可能性があると考えら れた。

なお， 74 日目（2002 年 8 月）に転覆していた試験礁 (VA1-2, VA2-2, VAS1-1, VAS2-1), および 140 日目 (2002 年 10 月) に埋没していた試験礁（VA1-2,VA32, VAS2-1, C-1 が完全埋没, VA2-2, VAS1-2 が一部埋 没）には試験期間を通してテングサの着生が確認できな かったが，これが転覆や埋没の影響によるものかどうか は, テングサの着生した試験礁における着生数が少な く，また，転覆打よび埋没していない 2 礁（VA3-1, VAS3-1）にテングサの着生が確認できなかったため不 明である。

組成・圧縮強度別試験礁の性質とテングサ着生状況の 関係 組成・圧縮強度別試験礁へのテングサの着生は, 目視観察によれば, 設置から 251 日目 (2003 年 2 月) に 14 礁中 3 礁（VAS2-2, VAS3-2, C-2）でマクサを 1 株ずつ確認できた。その後 468 日目までは新たな着生 は確認されず，560日目（2003年 12 月）に 3 礁（VA1 -1, VA2-1, VAS2-2）で新たにマクサが 1 株ずつ確認 された。またここれらすべてのマクサの着生箇所は稜角 や側面であり，追跡調査を終了した 648 日目（2004 年 3 月）まで枯死することなく生長した。しかしながら， マクサの着生した試験礁は, 組成および圧縮強度が異な る 5 礁であり, また, 着生数は 4 礁が 1 株, 1 礁が 2 株 と少なく, 組成や圧縮強度の違いとテングサの着生状況
の関係は明確に現れなかった。

組成・圧縮強度別試験礁の性質と紅藻類被度の関係 組成・圧縮強度別試験終了後に製作した円柱形の火山灰 ブロックの材料組成を決める際の参考とするため, 組成 - 圧縮強度別試験礁上面の画像から求めた紅藻類の被度 の比較を行った。その結果, コンクリートブロック C の被度は, 468 日目 (2003 年 9 月) 以降, 7 種類中常 に最大であり，2003 年 9 月はVAS3 以外の 5 種類の礁 に対して, 2003 年 12 月はVA1, VAS2 に対して, 2004 年 3 月はVAS2 以外の 5 種類の試験礁に対して有意差 が認められた $(P<0.05)$ 。一方, 火山灰やスコリアを 用いた 6 種類の試験礁の被度には, 2003 年 4 月以外, 有意差が認められなかった。また, 今回, 一部の試験礁 で転覆（2002 年 8 月）, 埋没（2002 年 10 月）が起こっ ているが， 2002 年 12 月，打よび 2003 年 2 月におい て, 各試験礁間における紅藻類被度に有意差が無かった ことから, 影響は軽微であったと推察される。これらの ことから, 火山灰を使用したブロックは, 概して, コン クリートブロックよりも紅藻類の被度が低く, また, 本 試験に打ける組成や圧縮強度の範囲（6.1～221.3 kgf/ $\left.\mathrm{cm}^{2}\right)$ に抢いては, 紅藻類の被度に差は出ないものと考 えられた。

火山灰を使用したブロックが，コンクリートブロック よりも紅藻類の被度が低い原因は今のところ明確ではな い。若杉ら ${ }^{11)}$ は三宅島火山灰から溶出する硫黄化合物 について調べ, $1 \mathrm{~g}$ の火山灰から $0.0116 \mathrm{~g}$ の硫酸イオン が溶出すると報告している。火山灰を使用した試験礁か らも硫酸イオンの溶出は考元らるが, 火山灰そのもの よりは少ないと考えられる。火山灰を使用したブロック で紅藻類の被度が低かった理由として, この微量の硫酸 イオンが着生や生長に影響した可能性もある。今後, 検 討しなければならない。

円柱形火山灰ブロックへのテングサの着生 組成・圧 縮強度別試験に抢いて, 火山灰を含むブロックに抢ける 紅藻類の被度は, 圧縮強度 $6.1 \sim 221.3 \mathrm{kgf} / \mathrm{cm}^{2}$ の範囲 では有意差が無く, コンクリートブロックとの比較では 有意に低かった。また, マクサはブロックの稜角, 側 面, および試験礁移設用の金具などの突起に多く着生す ることがわかった。これらの結果を基に, 円柱形火山灰 ブロックを製作し，テングサの着生を検討した結果，鉛 直面にオオブサが多数着生した。また, 着生量は円柱形 コンクリートブロックをやや下回る程度であった。すな わち, 円柱形の火山灰ブロックは, コンクリートブロッ クと同様に, テングサを生育させるための海藻礁として 使用できる可能性が高いと考えられた。一方, 円柱形火 山灰ブロックに着生したテングサは, 先に設置した試験 礁とは異なり, オオブサであった。この一因としては, 静岡県稲取町地先のマクサ, オオブサと, 千葉県小湊町 
地先のマクサを観察した結果，生殖細胞の形成及び成熟 の時期は個々によって違っていたとの殖田7)の報告を参 考とすれば，先に設置した試験礁との設置時期の違いが 影響した可能性があると考えられた。

火山灰を利用した海藻礁のテングサ礁としての評価 以上のことから，三宅島の荒廃したテングサ漁場の再生 を目的とした海藻礁の材料として，火山灰を利用できる 可能性は高いと考えられた。一方，三宅島では現在も火 山灰を含んだ泥流が周辺海域へ流出しており，テングサ 漁場には多量の海中懸濁粒子および海底堆積粒子が存在 する12)。今後は,このような条件下において，テング サの着生, 生育が可能な火山灰ブロックについて検討し ていくことが課題である。粒子の堆積がテングサの着生 に及ぼす影響に関する報告は無いが，褐藻類のアラメ Eisenia bicyclis やカジメEcklonia cavaに抢いては，粒 子の堆積が遊走子の着生を阻害することが知られてい る。13,14) また, 今回, 組成・圧縮強度別試験礁におい て, テングサの着生が確認できなかった上面部分は, 稜 角や側面部分と比較して砂の堆積量が明らかに多かっ た。したがって, 砂等の堆積粒子がテングサの着生に与 える影響について明らかにすることが必要である。ま た, 今回, 形状と設置時期が異なる 2 回の試験におい て, 着生するテングサの種が違ったことから，マクサ， およびオオブサの着生に適した基質の形状, および着生 基質の設置時期についても検討する必要がある。さら に, 火山灰を利用した海藻礁における海藻の遷移を長期 間調査していくことも, 耐久性を含めた効果を明らかに する上で重要であると考えられる。

\section{謝辞}

三宅島に抢ける火山灰の採集に関して，ご協力ご配慮 いただいた，東京都三宅支庁産業課（現所属，東京都小 笠原支庁産業課）永坂彰氏, 東京都水産課（現所属, 東 京都大島支庁産業課）小島修氏に深堪なる謝意を表しま
す。また, 海藻類の同定をしていただいた東京海洋大学 大葉英雄博士, 研究内容に関する助言や野外調查に協力 していたたいた東京都島しょ農林水産総合センター職員 の方々に深堪なる謝意を表します。

\section{文献}

1）河西一彦. 昭和 58 年三宅島噴火災害漁場調查報告書. 東 京都水産試験場調査研究要報 1988; 195: 1-83.

2) 米山純夫. 三宅島噴火災害漁場調査 I (被害状況の把 握). 事業成果速報 (平成 13 年). 東京都水産試験場, 東京. $2002 ; 11$.

3）川辺勝俊. 平成 17 年三宅島磯根資源調査-3（マクサモ ニタリング調査). 事業成果速報 (平成 17 年). 東京都 島しょ農林水産総合センター, 東京. $2006 ; 81$.

4) 東京都の水産 (平成 11 年版). 東京都労働経済局農林水 産部水産課, 東京. $2002 ; 42-46$

5）東京都の水産 (平成 18 年版). 東京都産業労働局農林水 産部水産課, 東京. $2007 ; 125-126$

6）土質試験の方法と解説. 土質工学会, 東京. 1990; 43.

7）殖田三郎. テングサの増殖に関する研究. 日水誌 1936 ; 5: $183-186$.

8）片田 実. テングサの増殖に関する基礎的研究. 水講所 研報 1955; 5: 1-87.

9）山崎 浩. テングサ類増殖に関する基礎的研究. 静岡水 試研報 1962; 19: 2-90.

10）大須賀穂作，岩橋義人．形の異なるコンクリートブロッ クによるテングサの着生試験. 静岡水試研報 1966; 31 : 1-6.

11）若杉幸子, 田中美穂, 前田 勝. 三宅島火山灰から水に 溶出する硫黄化合物の同定と定量および環境に及ぼす影 響. 分析化学 2003; 52: 997-1003.

12) H. Arakawa, Y. Nakayama, T. Morinaga. Distribution and behavior of high turbidity water on the shallow sea area around Miyake-shima Island. La mer. 2007; 45: 2334.

13）荒川久幸, 松生洽. 褐藻類ワカメ・カジメ遊走子の着生 と成長, 生残および成熟におよぼす海中懸濁粒子の影 響. 日水誌 1992; 58: 619-625.

14) H Arakawa. Lethal effects caused by suspended particles and sediment load on zoospore and gametophyte of the brown alga Eisenia bicyclis. Fish. Sci. 2005; 71: 133-140. 